\title{
Clathromorphum tubiforme sp. nov. (Rhodophyta, Corallinaceae) in South Africa with Comments on Generic Characters
}

\author{
Y. M. Chamberlain ${ }^{a, *}$, R. E. Norris ${ }^{b}$, D. W. Keats ${ }^{c}$ and G. Maneveldt \\ " Marine Laboratory, School of Biological Sciences, University of Portsmouth, Ferry Road, Hayling Island, PO11 0DG, \\ U.K. \\ b 4700 Westridge Avenue, Fort Worth, Texas, 76116-8219, U. S. A. \\ c Department of Botany, University of the Western Cape, Private Bag X17, Bellville 7535, Rep. of. South Africa \\ * Corresponding author
}

A nongeniculate, crustose coralline alga (Rhodophyta, Corallinaceae) from South Africa, is found growing epiphytically on fronds of species of the geniculate genus Amphiroa. Analysis of the vegetative and reproductive morphology and anatomy of the alga shows that it belongs to the subfamily Melobesioideae and genus Clathromorphum. It is the only known representative of the genus in South Africa. It has tetrasporangial conceptacles that are significantly smaller than those of any other described species of the genus and it is described as the new species Clathromorphum tubiforme. The diagnostic features of Clathromorphum and other genera of the Melobesioideae are discussed and it is considered that, among melobesioid genera, Clathropmorphum is probably most closely related to Melobesia.

\section{Introduction}

A study is being made of the taxonomy of South African nongeniculate coralline algae based on collections made by Yvonne Chamberlain, Richard Norris, Derek Keats and other colleagues. Priority is being given to studying ecologically significant species [e.g. Spongites yendoi (Foslie) Y. Chamberlain, Chamberlain 1993, Keats et al. 1992] and new or otherwise taxonomically interesting species [e.g. Pneophyllum amplexifrons (Harvey) Chamberlain et Norris, Chamberlain and Norris $1994 \mathrm{a}$; Hydrolithon pellire Chamberlain et Norris, Chamberlain and Norris 1994 b; Heydrichia spp., Townsend et al. 1994, Keats and Chamberlain 1995; Sporolithon spp., Keats and Chamberlain 1993; Leptophytum spp., Chamberlain and Keats 1994; Pneophyllum and Spongites spp., Chamberlain 1994; and Hydrolithon spp., Keats and Chamberlain 1994].

A map and background historical information are provided in Chamberlain (1993).

An epiphytic species was found growing on fronds of Amphiroa spp. It has the generic characters diagnostic of Clathromorphum Foslie and it is described and compared with all other known species of the genus. The relationship of the genus Clathromorphum to Melobesia is discussed.

\section{Materials and Methods}

Field collections were made in Cape Province and Natal, South Africa. Plants were examined as far as possible when fresh, or were air dried, or fixed in neutralized $10 \%$ commercial Formalin seawater $(4 \%$ formaldehyde) and stored in a 70\% ethanol : $10 \%$ glycerol : $20 \%$ water solution. Plants were decalcified for sectioning with Perenyi's fluid (4 parts $10 \%$ nitric acid : 3 parts $90 \%$ ethanol : 3 parts $0.5 \%$ chromic acid), the thallus was hardened in $80 \%$ ethanol and sectioned at $10-20 \mu \mathrm{m}$ thickness on a Mectron freezing microtome. Sections were mounted on a microscope slide in 50\% Karo corn syrup coloured with either aniline blue or $4 \%$ potassium permanganate.

For scanning electron microscopy (SEM), specimens were rinsed in demineralised water and air dried. Whole thalli or fractures were mounted on double-sided sticky tape, coated with gold/palladium and examined in a Joel T20, or Hitachi X650 scanning electron microscope at $20 \mathrm{KV}$.

In cell measurements, length denotes the distance between primary pit-connections, and diameter the width of the cell lumen at right angles to this. Conceptacle measurements follow the method adopted by Adey and Adey (1973). Thallus terminology follows Chamberlain (1990) for the monomerous thallus in which the multi-stratose lower filaments are termed the medulla and the filaments derived peripherally from these the cortex.

Drawings are made on the basis of individual slide preparations and are not composite representations.

Abbreviations: VS = vertical section; YMC 89/ 303, NAT, COR etc. are the authors' collection numbers.

\section{Observations}

Clathromorphum tubiforme Y. Chamberlain, R. Norris, D. Keats et G. Maneveldt sp. nov. 
Etymology: Tubiforme means tubular and refers to the tubes formed when this species completely encircles terete fronds of Amphiroa spp.

Holotype: L (Rijksherbarium, Leiden, The Netherlands). Cintsa, Eastern Cape Province, South Africa; in intertidal pools, epiphytic on Amphiroa ephedraea (Lamarck) Decaisne ( $R$. Anderson and J. Bolton, July 1967, YMC 89/206) (Figs 2-5, 7, 8, 10-30).

\section{Diagnosis}

Thallus in Amphiroam epiphyticus, applanatus, tubularis esse mutans, monomerus; strata cellularum epithallialium numero ad 7; lumina conceptaculorum tetrasporangialium diametro 59-73 $\mu \mathrm{m}, 39-52 \mu \mathrm{m}$ alta, tectum 10-13 $\mu \mathrm{m}$ crassum; tetrasporangia zonatim divisa, 30-52 $\mu \mathrm{m}$ longa, diametro 12-20 $\mu \mathrm{m}$.

Thallus epiphytic on Amphiroa spp., applanate, becoming tubular, monomerous; up to 7 layers of epithallial cells; tetrasporangial conceptacles flush with thallus surface, chambers $59-73 \mu \mathrm{m}$ in diameter, $39-52 \mu \mathrm{m}$ high, with the roof $10-13 \mu \mathrm{m}$ thick; tetrasporangia zonately divided, $30-52 \mu \mathrm{m}$ long $\times 12-$ $20 \mu \mathrm{m}$ in diameter.

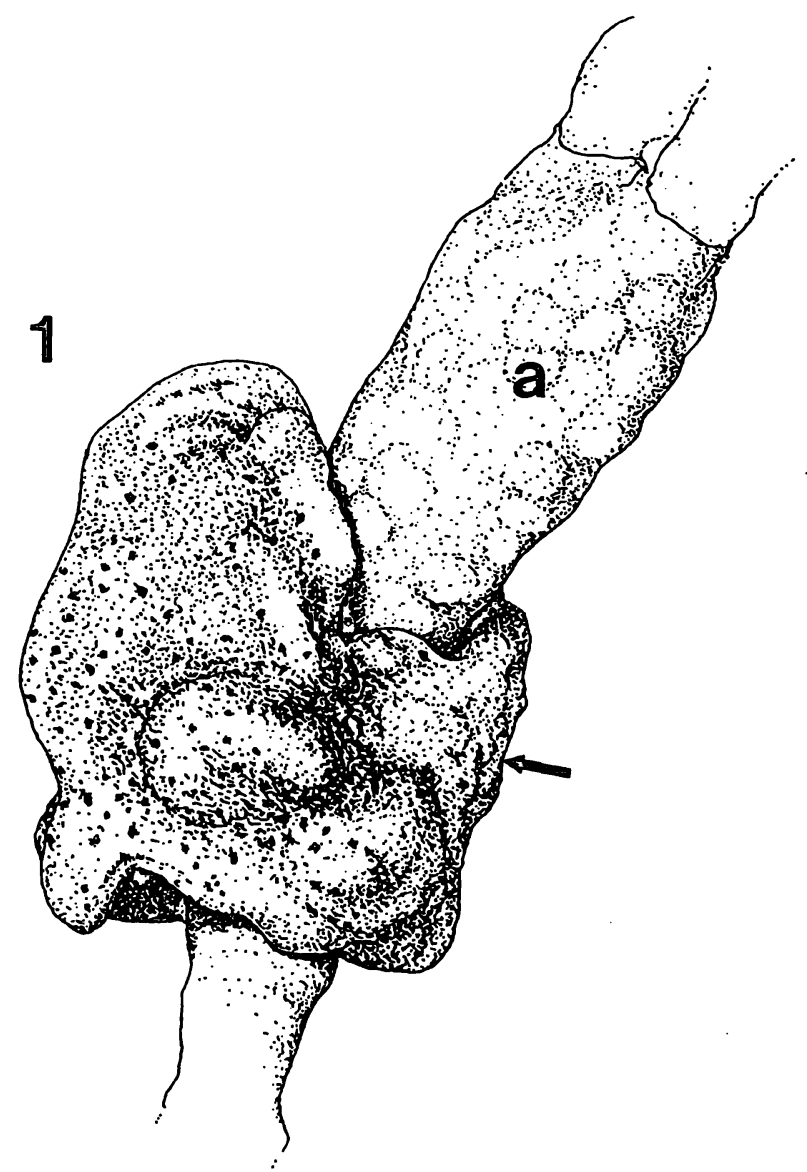

$2 \mathbf{m m}$

Fig. 1. A gametangial plant of Clathromorphum tubiforme (arrow) growing on Amphiroa anceps - note Amphiroa conceptacles (a) (NAT 6156).
Differing from all other described species of Clathromorphum in having small tetrasporangial conceptacle chambers with a maximum diameter of $73 \mu \mathrm{m}$.

Representative specimens examined: Natal: Tiger Rocks, on Amphiroa anceps (Lamarck) Decaisne, $R E N$, intertidal, 7. iv. 1989, NAT 6156; Cape Province: Partridge Point, False Bay, on Amphiroa sp., $D W K$ and $G M, 12 \mathrm{~m}$ depth, 6. viii. 1993, UWC 93/ 104; $G M$ and $D W K, 8-14 \mathrm{~m}$ depth, 14. ix. 1993, UWC 93/219.

\section{Habitat and seasonality}

Growing epiphytically on fronds of Amphiroa ephedraea, A. anceps and Amphiroa sp. in intertidal pools and subtidally to at least $16 \mathrm{~m}$. All types of reproductive organs were found from July to October, no data are available for other months.

\section{Habit and vegetative structure}

Measurements are given in Table I. Thalli (Figs 1-4) are encrusting, adherent and measure up to at least $20 \mathrm{~mm}$ in diameter. The margin is entire with the extreme edge being conspicuously hyaline. Young thalli are more or less circular but older thalli become confluent. Adjacent thalli are mainly flat where they meet but sometimes overlap one another slightly. Older thalli do not form margins free of the host but often encircle Amphiroa fronds completely (Figs 1, 17). Cells in surface view (SEM) are of the Phymatolithon-type (Fig. 5) with calcereous rims encircling concavities (see Chamberlain 1990). The thallus surface is smooth, silky (i.e. neither obviously matt nor glossy) and the colour is pink.

Conceptacles occur over the entire thallus except for the immedate marginal area. Gametangial conceptacles (Figs 1,3) are slightly raised with sunken pores. Tetrasporangial conceptacles (Figs 4, 9) are sunken below the thallus surface and appear as densely crowded, minute holes. The pore plate (Figs $9,10)$ is often difficult to see in surface view, it measures up to ca. $100 \mu \mathrm{m}$ in diameter and bears up to 18 pores. Each pore (Figs 10,30) is surrounded by a rosette of 5-7 cells.

The thallus is monomerous throughout (Figs 6, 12, 13, 18, 24). Terminal initials (Fig. 19), at thallus margins, are elongate. Tubular thalli in transverse section (Fig. 17) often give no indication as to where the two thallus edges encircling the Amphiroa frond originally joined. Adjacent thalli may also fuse similarly. The medulla is plumose (Figs 6,11-13) and is up to 8 filaments thick. Cells are elongate (Table I) with long, thin, mainly pear-shaped lumens (Figs 11, 19). Medullary filaments terminate on the ventral surface in somewhat swollen cells (Fig. 11) resembling uppermost dorsal epithallial cells (Fig. 11). 
The cortex sometimes appears zonate; it is composed of cells (Fig. 11) with long, thin, often pearshaped lumens. Narrow cell fusions between adjacent cells of contiguous filaments occur rather infrequently in the medulla and cortex (Fig. 11). When cells fracture along the middle lamella, SEMs (Fig. 6) show mainly calcified cell walls with small holes through which fusions have occurred. Subepithallial initials (Fig. 11) are elongate unless recently divided, they stain more densely than surrounding cells; they are similar in size to their immediate inward derivatives. Epithallial cells (Fig. 11) are squarish to elongate; they occur up to 7 layers thick. The uppermost cell has a flat, non-flared outer cell wall (Fig. 11). Trichocytes were not seen.

\section{Reproduction}

Measurements are given in Table I. Gametangial plants are dioecious. Male conceptacle chambers (Figs 12, 15) are elliptical. The roof (Fig. 15) is composed of cells similar to cortical and epithallial layers of the vegetative thallus. The pore canal is either parallel-sided (Fig. 15) or somewhat tapering upwards and is lined with elongate papillae. Simple spermatangial systems (Fig. 16) occur on all conceptacle chamber surfaces (Fig. 15).

Carpogonial conceptacle chambers (Fig. 20) are wide and shallow, the structure of the roof and pore canal structure are similar to those of male conceptacles. Carpogonial branches are borne in the centre of the conceptacle floor (Fig. 20), each supporting cell bears a single hypogynous cell and carpogonium (Fig. 21). Carposporangial conceptacle chambers (Figs 6, 13, 22) are wide and shallow and carpogonial remnants occur in the centre of the conceptacle floor (Fig. 22). The fusion cell is central (Fig. 22) and gives rise to connecting cells (Fig. 23) peripherally. Gonimoblast filaments comprise one or two cells plus an enlarged carposporangium (Figs 22, 23); they are borne peripherally on apparently discrete connecting cells.

Tetrasporangial conceptacle chambers (Figs 24, 27) are elliptical. The roof (Fig. 10) is slightly sunken below the thallus surface and is two to four cells thick. Pore plugs (Fig. 29) are conspicuous and are not lined by specialised roof cells. The zonately divided tetrasporangia (Fig. 27) are about twice as long as wide. Bisporangial plants are not known.

Old conceptacles of all types may become buried in the thallus (Fig. 24).

\section{Conceptacle and initiation and development}

Male conceptacles are initiated from, and immediately below, subepithallial initials. The primordium splits horizontally (Fig. 14) with the upper cells forming the roof and the lower cells becoming spermatangial initials. Eventually simple spermatangial systems develop on all surfaces and a pore canal develops in the centre of the roof (Fig. 15).
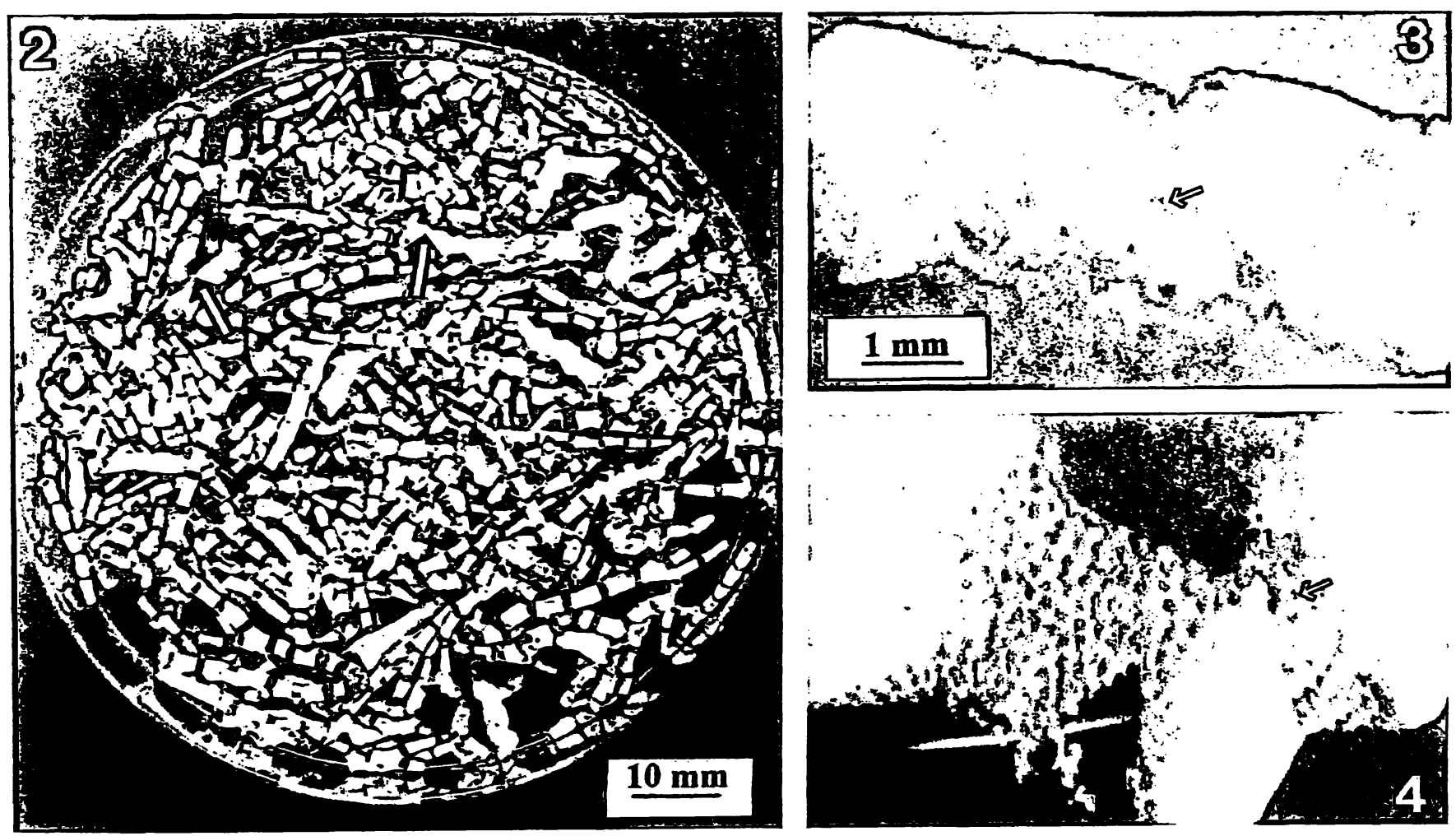

Figs 2-4. Holotype (L) of Clathromorphum tubiforme (YMC 89/206).

Fig. 2. Fragments of Amphiroa ephedraea bearing $C$. tubiforme thalli (arrows). Fig. 3. Gametangial thallus with uniporate conceptacles (arrow). Fig. 4. Tetrasporangial thallus with multiporate conceptacles (arrow) (scale as Fig. 3 ). 

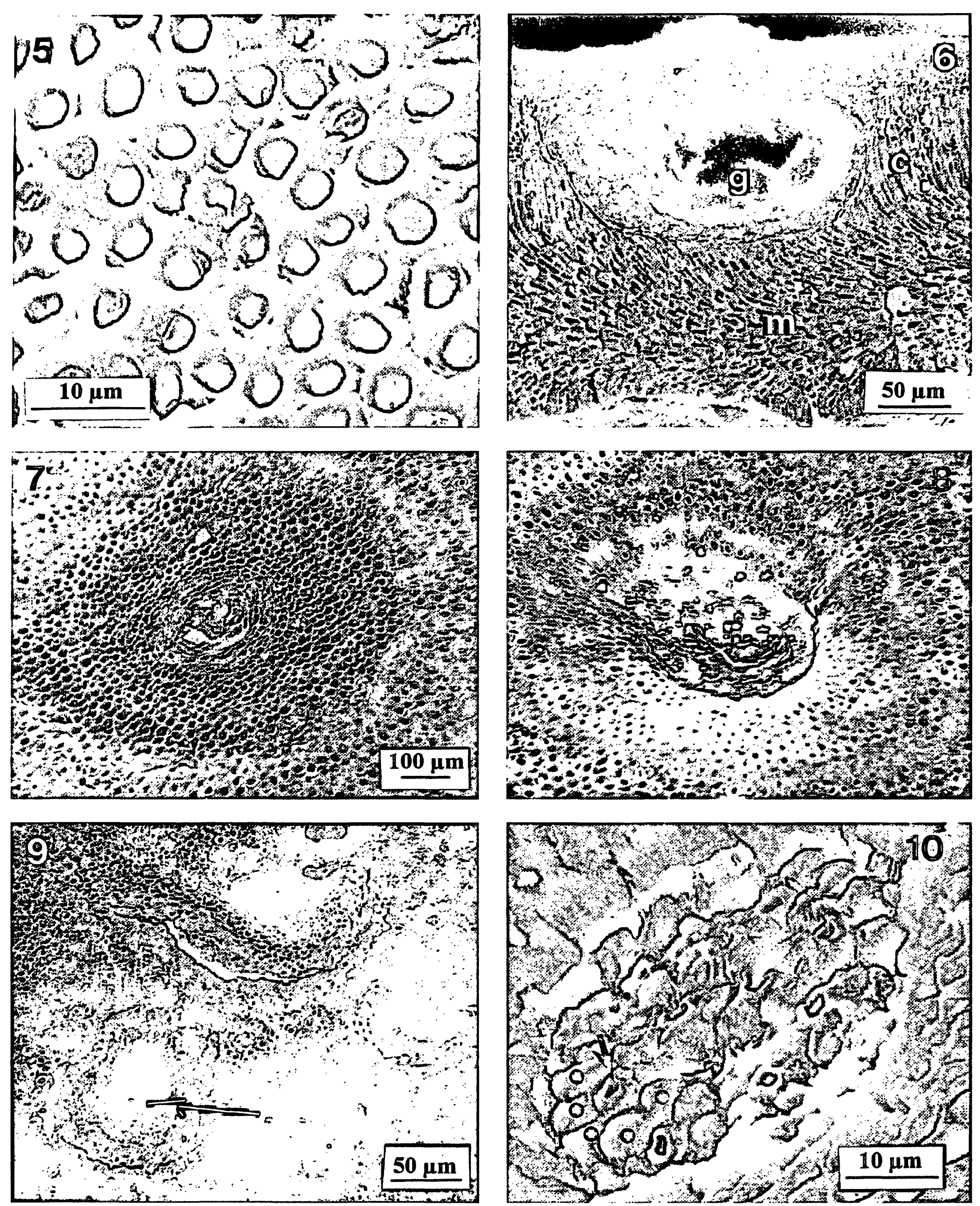

Figs 5-10. Clathromorphum tubiforme.

Fig. 5. Thallus surface (holotype). Fig. 6. VS carpogonial conceptacle containing a gonimoblast filament (g); note plumose medullary filaments (m) and cortical filaments fractured through middle lamellae (c) (UWC). Fig. 7. Flat roof of carpogonial conceptacle (holotype). Fig. 8. Roof of carposporangial conceptacle with sunken .pore (holotype) (scale as Fig. 7). Fig. 9. Surface of tetrasporangial thallus with sunken conceptacle pore plates (arrow) (UWC). Fig. 10. Detail of tetrasporangial pore plate with pore (arrow) surrounded by six rosette cells (black dots) (holotype). 
Tetrasporangial conceptacles are initiated in subepithallial cells (Fig. 25). These give rise to tetrasporangial initials (Figs 25,26 ) terminating above in pore plugs interspersed among young pore-plate filaments. Overlying epithallial cells are shed at this stage leav- ing the immature (Fig. 26) and mature (Fig. 27) roof slightly sunken below the thallus surface. After tetrasporangia have been shed, thallus cells surrounding the chamber elongate (Fig. 28) and the top of the chamber becomes infilled with newly produced small
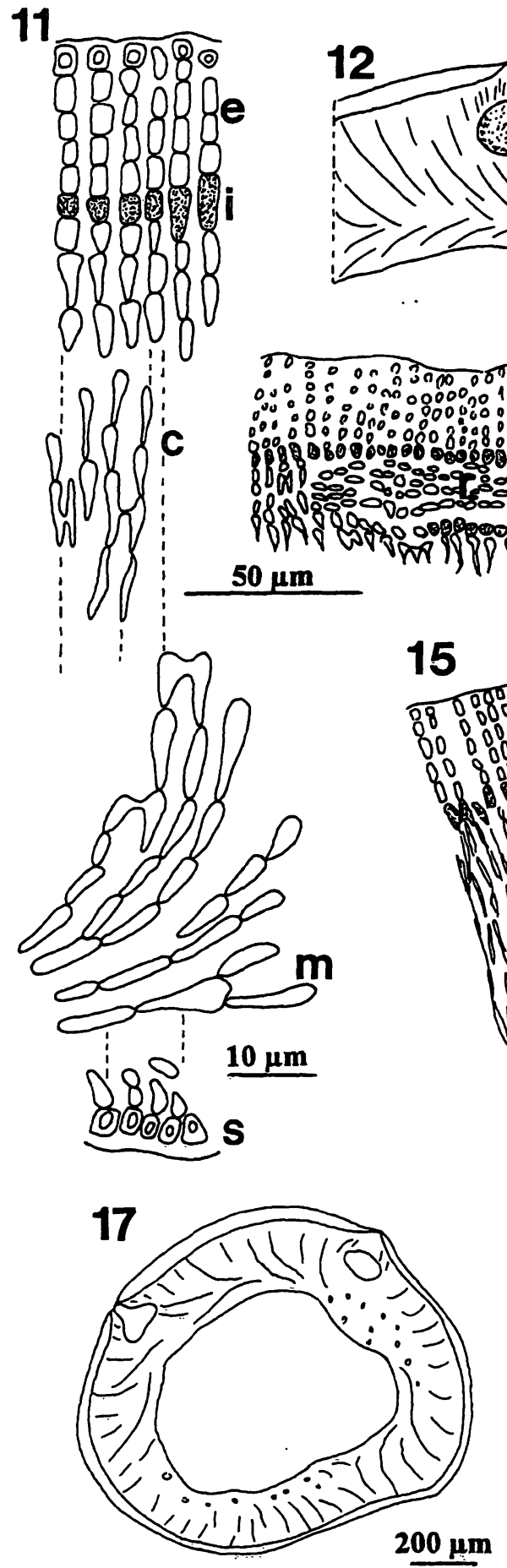

15

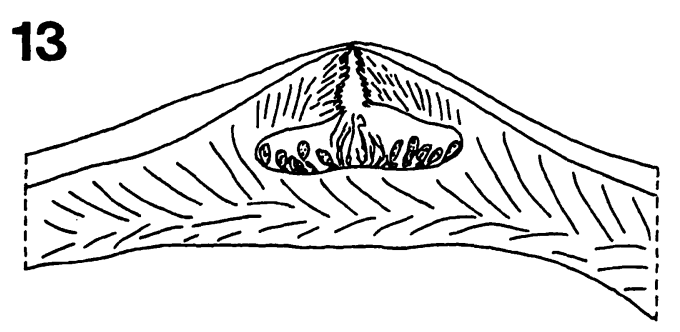

14

13
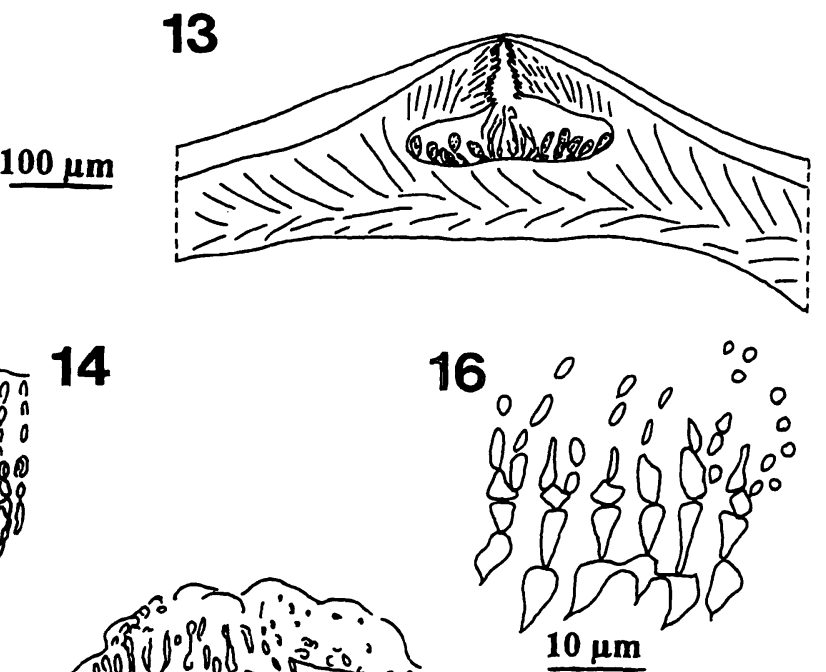
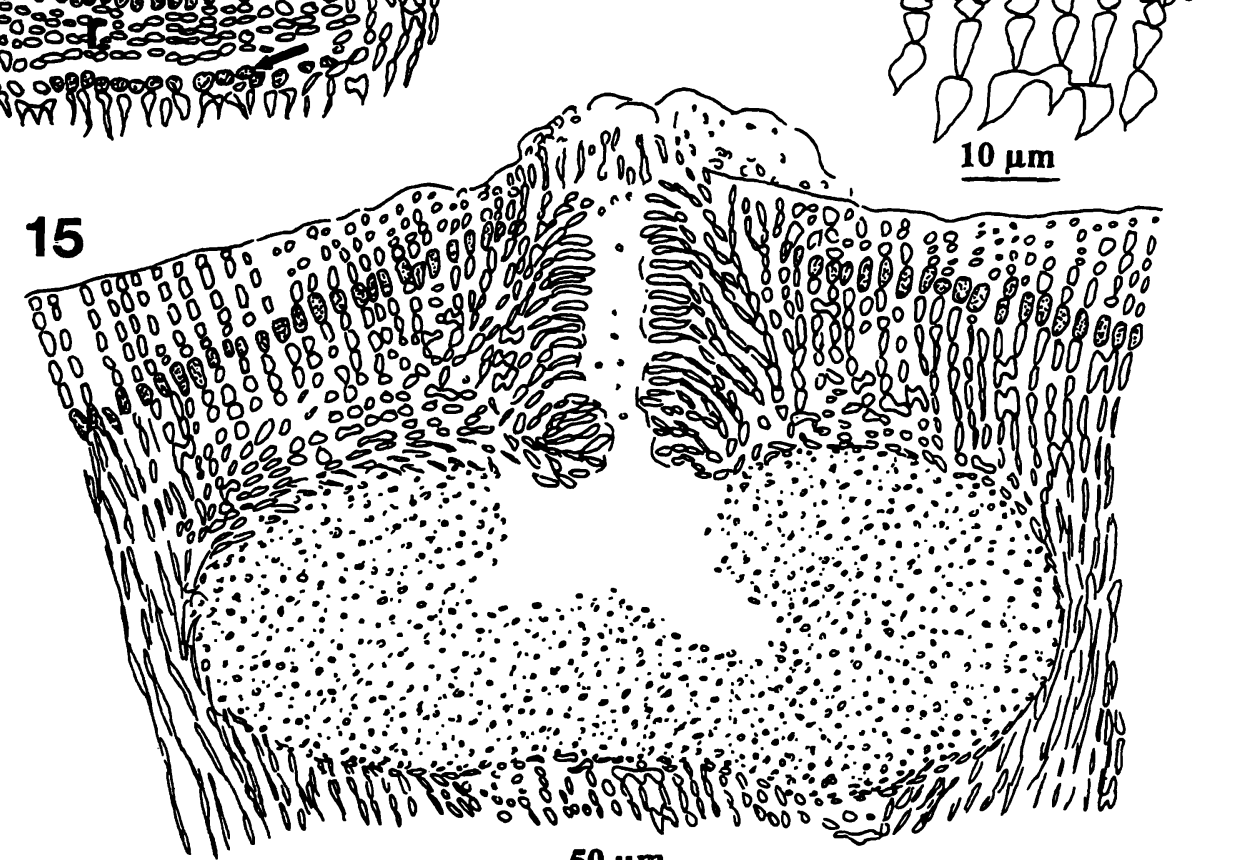

$50 \mu \mathrm{m}$

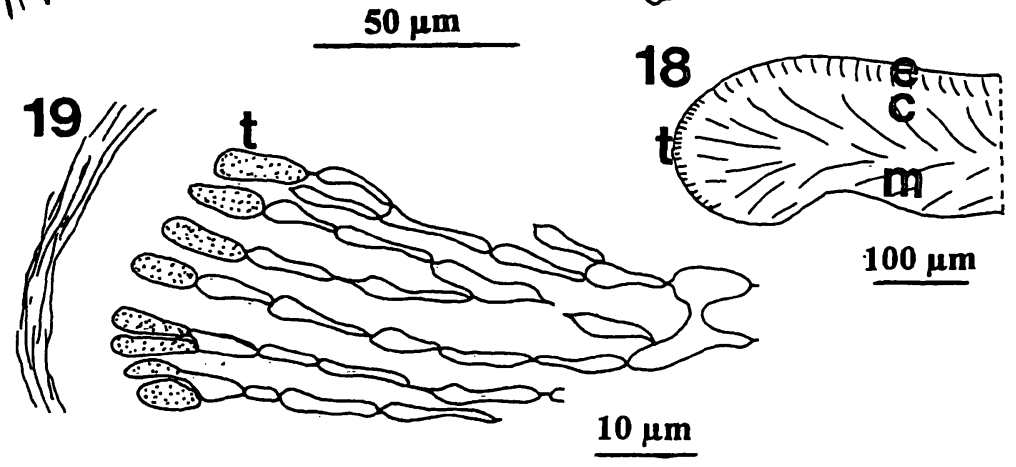

Figs 11-19. Vertical sections of holotype (YMC 89/206) of Clathromorphum tubiforme.

Fig. 11. To show thallus components, $\mathrm{e}=$ epithallial filaments, $\mathrm{i}=$ subepithallial initials, $\mathrm{c}=$ cortical filaments, $\mathrm{m}=$ medullary filaments, $s=$ epithallial-like cells on lower surface. Fig. 12. Diagrammatic drawing of thallus with spermatangial conceptacle, note epithallial layers (e), cortex (c) and medulla (m). Fig. 13. Diagrammatic drawing of thallus with carposporangial conceptacle. Fig. 14. Early developmental stage of male conceptacle with spermatangial initials (arrow) and developing roof $(r)$ - note the horizontal split between roof cells and spermatangial initials. Fig. 15. Mature male conceptacle with simple spermatangial systems all round the chamber, note papillae lining pore canal. Fig. 17. Diagrammatic drawing to show male thallus completely encircling the host. Fig. 18. Diagrammatic drawing of margin of monomerous thallus showing terminal initials $(\mathrm{t})$, medulla $(\mathrm{m})$, cortex $(\mathrm{c})$ and epithallial layers (e). Fig. 19. Detail of extreme edge of monomerous thallus showing terminal initials $(\mathrm{t})$. 
cells and the remains of old sporangia. The pore plate appears to arch upward, possibly this is the result of mucilaginous swelling. Gradually the surrounding vegetative cortex overgrows the chamber which persists and becomes buried in the lower part of the thallus (Fig. 24).

\section{Discussion}

\section{Generic identification}

Clathromorphum, type species C. compactum (Kjellman) Foslie, was erected by Foslie (1898) (see summary in Mason, 1953: 330) and emended by Adey (1965) to include melobesioid species with a thick epithallium and strongly defined subepithallial initials. Lebednik (1977 a: 62-63) summarises the complex history of the genus when he redescribes six species from western North America. Woelkerling (1988: 163) further summarises the history of the genus and notes that gametangial conceptacles are unknown in the type species. Thus any proposed generic characters based on gametangial features cannot be confirmed in the type species.
Woelkerling (1988: 158) lists the diagnostic characters of Clathromorphum as follows (Woelkerling's italics): '(1) a non-taeniform habit; (2) haustoria unknown; (3) a thallus which includes a ventral or central core of noncoaxial filaments; (4) terminal epithallial cells with rounded or flattened but not flared outermost cell walls; (5) vegetative initials as long as or longer than their immediate inward derivatives; and (6) tetrasporangial/bisporangial conceptacles which develop from groups of subepithallial initials'.

Clathromorphum tubiforme agrees with all the generic characters listed by Woelkerling (1988). In addition, details of male conceptacle initiation and the structure and disposition of spermatangial systems conform to those attributed to the genus by Adey (1965), Adey and Johansen (1972) and Lebednik $(1977 \mathrm{a}, 1978)$. The male conceptacle primordium develops in cells cut off from, and subtending, subepithallial initials. The chamber develops below by splitting between successive layers of cells, and the roof develops above. This type of development was established by Adey (1965) and Adey and Johansen (1972) for several species now attributed
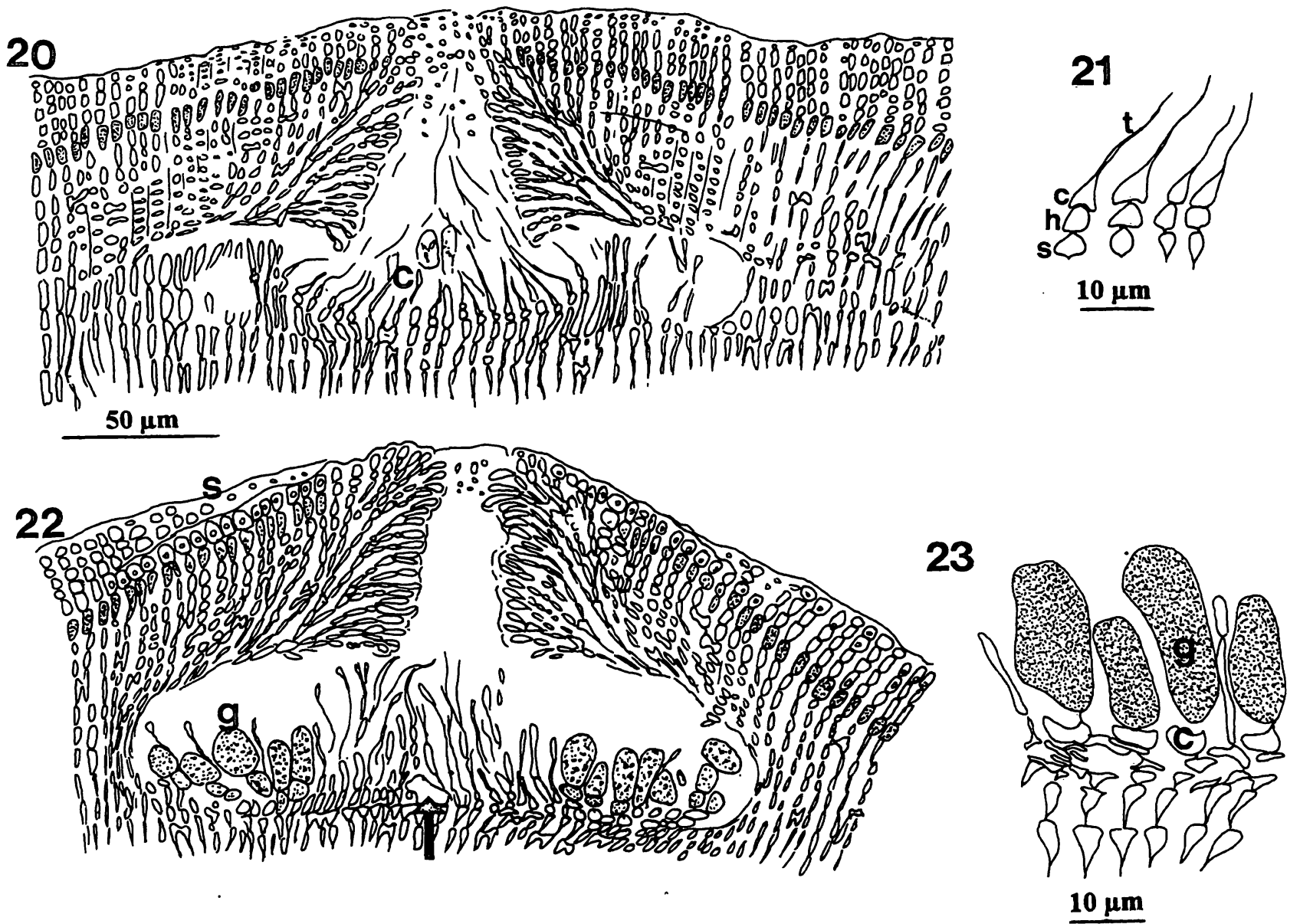

Figs 20-23. Vertical sections of holotype (YMC 89/206) of Clathromorphum tubiforme.

Fig. 20. Carpogonial conceptacle with central carpogonial branches (c). Fig. 21. Carpogonial branches showing supporting cell (s), hypogynous cell (h) and carpogonium (c) extending into a trichogyne (t). Fig. 22. Carposporangial conceptacle with shedding surface (s), fusion cell (arrow) and peripheral gonimoblast filaments (g). Scale as Figure 20. Fig. 23. Periphery of carposporangial conceptacle floor showing connecting cells (c) and young gonimoblast filaments (g). 
to Clathromorphum. It was subsequently used by Lebednik (1977 a, fig. 15; 1978, figs 11,12 ) as one of the characters distinguishing Clathromorphum from Mesophyllum in which the male conceptacle roof develops from filaments surrounding spermatangial initials. The two genera share the character of having simple spermatangial systems on all conceptacle surfaces.

Chamberlain (1990, p. 181) noted two types of epithallial cell surface structure as seen under SEM. In British Isles species of Leptophytum she noted the presence of flat cell surfaces, with minute central holes, surrounded by thin calcareous ridges. In Phymatolithon epithallial concavities surrounded by thickened calcareous ridges were present. These were termed Leptophytum-type and Phymatolithontype surfaces respectively. It was noted that both types of surface occurred in Leptophytum depending on the age and condition of the surface cells in question. Chamberlain (1990) also noted that the Leptophytum-type surface occurred in Clathromorphum reclinatum (Foslie) Adey as shown by Garbary and Scagel (1979, fig. 5). Since 1990 the epithallial surface characters of many crustose coralline algae have been noted (Chamberlain and Keats personal observations) and it has become apparent that, while this is a useful character in species recognition, it can only be used for generic determination in local situations.

\section{Consideration of Melobesioid genera}

Woelkerling (1988: 191) lists a group of Melobesioideae comprising Clathromorphum, Melobesia, Phymatolithon and Synarthrophyton as having the following characters in common: (1) lack haustoria; (2) are not taeniform; (3) do not produce terminal epithallial cells with flared outer walls; (4) do not have a coaxial score of filaments. He distinguishes Melobesia, type species $M$. membranacea (Esper) Lamouroux, from the other genera on the basis of having a strictly dimerous thallus and comments that Melobesia has no obviously close relationship to any other genus. Woelkerling (1988: 166) further distinguishes Clathromorphum with simple spermatangial systems all round the conceptacle surface from Phymatolithon and Synarthrophyton which have dendroid systems at least on the conceptacle floor. It should be remembered, however, that this feature has not been confirmed in the type species of Clathromorphum.

Further analysis of the literature reveals, however, that in reproductive, as opposed to vegetative, features Melobesia, type species $M$. membranacea (Esper) Lamouroux, and Clathromorphum are similar. The relevant features are compared and contrasted below:

(i) Male conceptacle initiation.

In Clathromorphum subepithallial initials cut off two layers of spermatangial initials basipetally (Lebednik 1977 a, figs 15, 23; 1978, fig. 12) and the subepithall-

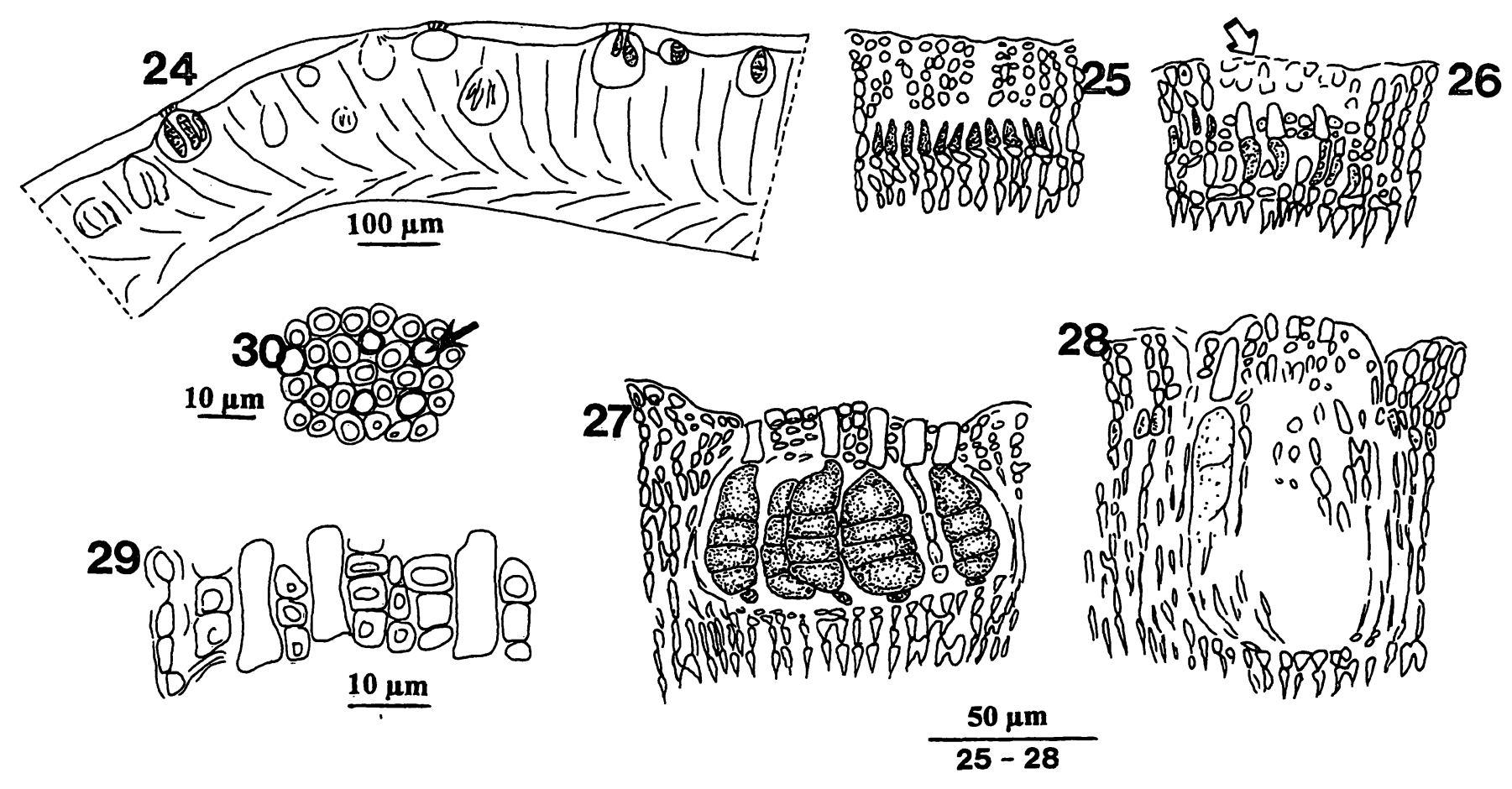

Figs 24-30. Tetrasporangial plants of holotype (YMC 89/206) of Clathromorphum tubiforme.

Figs 24-29. Vertical sections. Fig. 24. Diagrammatic drawing of thallus with tetrasporangial conceptacles at various stages of initiation, maturity and burying. Fig. 25. Conceptacle initiation, initials are shaded. Fig. 26. Young conceptacle with immature tetrasporangia (shaded) and old thallus being shed (arrow). Fig. 27. Mature conceptacle. Fig. 28. Old conceptacle which is becoming buried by the upward growth of the thallus. Fig. 29. Detail of pore plate. Fig. 30. Pore plate in surface view with pore (arrow) surrounded by rosette of cells. 
ial initials remain functional. No data are available for the type species $C$. compactum.

Lebednik (1978: 392) was not entirely certain whether initiation was in the subepithallial initial or deeper (adventitious) in Melobesia membranacea and no other author has provided data on this matter, presumably because it is difficult to see this feature in very small plants. (ii) Male conceptacle development and structure.

In Clathromorphum the conceptacle roof develops from vertically oriented filaments between the spermatangial initials and subepithallial initials (Lebednik $1977 \mathrm{a}$, figs 15a, b; 1978, fig. 12). The conceptacle chamber is created by the splitting apart of the two rows of spermatangial initials. Simple spermatangial systems are borne on floor, walls and roof of the ma-

Table I. Comparison of features of Clathromorphum tubiforme, C. reclinatum* and C. parcum*. Measurements in $\mu$ m.

\begin{tabular}{|c|c|c|c|}
\hline & C. tubiforme & C. reclinatum & C. parcum \\
\hline Hosts & Amphiroa & $\begin{array}{l}\text { Calliarthron, Bossiella, } \\
\text { Corallina, Ahnfeltia }\end{array}$ & Calliarthron \\
\hline Habit & Applanate to tubular & Peltate, circular & Peltate, circular \\
\hline Thallus thickness & up to 550 & $200-1000$ & up to 3000 \\
\hline \multicolumn{4}{|l|}{ Medulla } \\
\hline$\%$ of thallus & $<25 \%$ & $<15 \%$ & very little \\
\hline Cell length & $12-20$ & $24-\quad 59$ & - \\
\hline Cell diameter & $4-12$ & $5-16$ & - \\
\hline \multicolumn{4}{|l|}{ Cortex } \\
\hline Cell length & $6-13$ & $8-21$ & $9-25$ \\
\hline Cell diameter & $2.5-9$ & $5-12$ & $5-11$ \\
\hline \multicolumn{4}{|l|}{ Subepithallial initial } \\
\hline Cell length & $6-11$ & $18-\quad 39$ & $13-31$ \\
\hline Cell diameter & $6-10$ & $6-16$ & $7-13$ \\
\hline \multicolumn{4}{|l|}{ Epithallial cells } \\
\hline Number & $5-7$ & $1-2(3)$ & $3-5$ \\
\hline Cell length & $6-12$ & $4-\quad 10$ & $5-11$ \\
\hline Cell diameter & $5-10$ & $4-\quad 10$ & $6-12$ \\
\hline \multicolumn{4}{|l|}{ Male conceptacle chamber } \\
\hline Diameter & $169-247$ & $144-185$ & $443-639$ \\
\hline Height & $52-104$ & $75-113$ & $134-277$ \\
\hline Roof thickness & $47-78$ & $62-124$ & $93-196$ \\
\hline \multicolumn{4}{|l|}{ Carposporangial chamber } \\
\hline Diameter & $182-213$ & $288-371$ & $288-515$ \\
\hline Height & $52-65$ & $185-361$ & $134-209$ \\
\hline Roof thickness & $52-75$ & $72-103$ & $82-144$ \\
\hline \multicolumn{4}{|l|}{ Tetrasporangial chamber } \\
\hline Diameter & $59-73$ & $227-371$ & $361-556$ \\
\hline Height & $39-52$ & $155-299$ & $185-319$ \\
\hline Roof thickness & $10-13$ & $31-82$ & $72-103$ \\
\hline \multicolumn{4}{|l|}{ Tetrasporangium } \\
\hline Length & $30-52$ & c. 110 & c. 200 \\
\hline Diameter & $12-20$ & 30 & 105 \\
\hline Old tetrasporangial conceptacles & Becoming buried & Becoming buried & Becoming buried \\
\hline Distribution & South Africa & $\begin{array}{l}\text { Alaska to California; } \\
\text { Japan }\end{array}$ & $\begin{array}{l}\text { Washington } \\
\text { to California }\end{array}$ \\
\hline
\end{tabular}

* Data from Lebednik (1977 a) 
ture conceptacle. No data are available for C. compactum.

In Melobesia, Kylin (1928, figs 20A, B) showed similar development for Melobesia membranacea. Suneson (1937, as Epilithon) also discussed an apparently similar type of development for this species. Wilks and Woelkerling (1991, fig. 34) illustrated a conceptacle roof of $M$. rosanoffii (Foslie) Lemoine with a thickened roof suggesting the type of development described above.

(iii) Carpogonial conceptacle initiation.

In Clathromorphum the conceptacle is initiated in subepithallial initials (e. g. Adey and Johansen 1972, fig. 53; Lebednik 1978, fig. 4) but again no data are avaliable for $C$. compactum.

In Melobesia, an early stage illustrated by Kylin (1928, fig. 19E) for M. membranacea indicates subepithallial initiation. In other species such as $M$. pacifica Masaki (non Heydrich) (Masaki 1968, pls XXXIX, XI, fig. 1) and M. mediocris (Foslie) Setchell et Mason (Lee 1970, fig. 16) initiation takes place on such thin thalli that it is difficult to compare with Clathromorphum.

In all species of both genera carpogonial branches develop in the centre of the conceptacle floor and sterile structures develop peripherally.

(iv) Carposporangial conceptacle development and structure.

In Clathromorphum, after presumed karyogamy, a mainly small central fusion cell develops (Lebednik 1978, figs 9, 10,13). From this cell a series of connecting cells develops centrifugally, giving rise to peripheral gonimoblast filaments (Lebednik 1978, figs 10, 13, 16, 17). As noted by Lebednik (1978: 393) it is not always easy to distinguish fusion cells from connecting cells or to see the connections among the latter because they are only observable in some planes of section. Adey and Johansen (1972, fig. 54), for example, interpreted structures as intermittent fusion cells in C. reclinatum (as Neopolyporolithon). No data are available for $C$. compactum.

In Melobesia membranacea a central, continuous but bead-like fusion cell is shown by Kylin (1928, fig. 19G). Heydrich (1909, pl. IV, fig. 5), Wilks and Woelkerling (1991, fig. 21) and Chamberlain and Irvine (1994, fig. 94C), however, indicate a series of interconnected cells in this species. Possibly, as suggested by Lebednik (1978), a system of fusion and connecting cells occurs as in Clathromorphum.

(v) Tetrasporangial conceptacle initiation.

In Clathromorphum the primordium develops in subepithallial initials. Adey (1965, fig. 37) demonstrates this for C. compactum and other species and further confirmation of initiation site is provided by Lebednik (e. g. 1977 a, fig. 18a).

In Melobesia membranacea tetrasporangial conceptacles appear to be initiated by subepithallial initials (e.g. Kylin 1928, fig. 21A; Suneson 1937, fig.
36). Wilks and Woelkerling (1991: 519) interpret initiation as occurring one cell below subepithallial initials in $M$. membranacea and about five cells below in $M$. rosanoffii. Lee $(1970$, fig. 8) shows shallow initiation in $M$. mediocris but it is not evident whether it occurs in the subepithallial initial and it is generally difficult to determine the site of conceptacle initiation in Melobesia because the thalli are often very thin.

Insofar as data are available, therefore, conceptacle initiation, development and structure are very similar in Melobesia and Clathromorphum. In particular, male conceptacle roof development, together with chamber development involving thallus splitting, characterises both genera and is not seen in other melobesioid genera. The type of auxiliary cell apparatus involving fusion cells and connecting cells, as proposed by Lebednik (1977 b), also supports a relationship between Clathromorphum and Melobesia.

The genera can, however, be distinguished on vegetative anatomical grounds: Melobesia is dimerous, with a single epithallial layer and inconspicuous subepithallial initials; Clathromorphum is monomerous, with (mainly) 3-16 epithallial layers and a conspicuously elongate, deeply staining subepithallial initial.

We conclude, therefore, that Melobesia is more closely related to Clathromorphum than to other melobesioid genera. At the same time, we consider it is reasonable to maintain both Melobesia and Clathromorphum on the basis of vegetative diagnostic characters.

\section{Species distinctions}

Of the six species examined by Lebednik (1977a) Clathromorphum circumscriptum (Strömfelt) Foslie, C. compactum (the type species), C. loculosum (Kjellman) Foslie and $C$. nereostratum Lebednik are epilithic. Apart from habit, they also differ from C. tubiforme in having tetrasporangial conceptacle chambers at least $190 \mu \mathrm{m}$ in diameter. This is significantly larger than tetrasporangial conceptacles of $C$. tubiforme which measure a maximum of $73 \mu \mathrm{m}$ in diameter. Clathromorphum parcum (Setchell et Foslie) Adey and $C$. reclinatum, like $C$. tubiforme, are epiphytic on various algae including geniculate coralline species. These two species differ from $C$. tubiforme in having discoid thalli with free margins and significantly larger tetrasporangial conceptacles (Table I).

Finally, the germinating spore of $C$. parcum produces a 'foot' that is enveloped by the host thallus (Adey and Johansen 1972), whereas the thallus of $C$. tubiforme and $C$. reclinatum is entirely superficial on the host. This character is especially useful for identification.

The above six species have a Northern Hemisphere distribution. Two species from the Southern Hemisphere have been classified by Adey (1970) and Mendoza and Cabioch (1986) as Clathromorphum, viz. $C$. obtectulum (Foslie) Adey (1970) and C. lemoineae 
Mendoza et Cabioch (Mendoza and Cabioch 1986). According to the observations of Mendoza and Cabioch (1986), both species have Clathromorphum generic characters 1-5 (Woelkerling 1988 - see above) but conceptacle initiation and structure and spermatangial systems characteristics are unknown.

\section{Acknowledgements}

We are most grateful to the following colleagues: Bob Ross made the Latin translation; Rob Anderson and John Bolton collected the type specimen; Graham

\section{References}

Adey, W. H. 1965. The genus Clathromorphum in the Gulf of Maine. Hydrobiologia 26: 539-573.

Adey, W. H. 1970. A revision of the Foslie crustose coralline herbarium. K. Norske Vidensk. Selsk. Skr: 1970 (1): $1-46$.

Adey, W. H. and P. Adey. 1973. Studies on the biosystematics and ecology of the epilithic crustose Corallinaceae of the British Isles. Br: phycol. J. 8: 343-407.

Adey, W. H. and H. W. Johansen. 1972. Morphology and taxonomy of Corallinaceae with special reference to Clathromorphum, Mesophyllum, and Neopolyporolithon gen. nov. (Rhodophyceae, Cryptonemiales). Phycologia 11: 883-904.

Chamberlain, Y. M. 1990. The genus Leptophytum (Rhodophyta, Corallinales) in the British Isles with descriptions of Leptophytum bornetii, L. elatum sp. nov. and $L$. laeve. Br: phycol. J. 25: 179-199.

Chamberlain, Y. M. 1993. Observations on the crustose coralline red alga Spongites yendoi (Foslie) comb. nov. in South Africa and its relationship to $S$. decipiens (Foslie) comb. nov. and Lithophyllum natalense Foslie. Phycologia 32: 100-115.

Chamberlain, Y. M. 1994. Pneophyllum coronatum (Rosanoff) D. Penrose comb. nov., P. keatsii sp. nov., Spongites discoideus (Foslie) D. Penrose et Woelkerling and $S$. impar (Foslie) Y. Chamberlain comb. nov. (Rhodophyta, Corallinaceae) from South Africa. Phycologia 33: 141157.

Chamberlain, Y. M. and L. M. Irvine. 1994. Melobesioideae. In: (L. M. Irvine and Y. M. Chamberlain) Seaweeds of the British Isles, Vol. 1, Part 2B, Corallinales and Hildenbrandiales. HMSO, London. pp. 159-234.

Chamberlain, Y. M. and D. W. Keats. 1994. Three melobesioid crustose coralline red algae from South Africa: Leptophytum acervatum (Foslie) comb. nov., L. foveatum sp. nov. and $L$. ferox (Foslie) comb. nov. Phycologia 33: $111-133$.

Chamberlain, Y. M. and R. E. Norris 1994 a. Pneophyllum amplexifrons (Harvey) comb. nov., a mastophoroid, crustose coralline red algal epiphyte from South Africa. Phycologia 33: 8-18.

Chamberlain, Y. M. and R. E. Norris. 1994 b. Hydrolithon pellire sp. nov., a mastophoroid, crustose coralline red
Bremer and Colin Derrick helped with scanning electron microscopy and photography respectively, and Catherine Handforth drew Figure 1. Natural Environment Research Council (U.K.) Grant GR3/ 7464 is acknowledged by YMC. We acknowledge grants from: the Foundation for Research Development (FRD)-funded West Coast of South Africa Flora Project to John Bolton; the joint FRD-University Development Programme/University of the Western Cape research development programme; an FRD-core grant to DWK.

Accepted 4 August 1995

algal epiphyte from South Africa. Phycologia 33: 291297.

Foslie, M. 1898. Systematical survey of the lithothamnia. Det K. norske Vidensk. Selsk. Skr. 1898 (2): 1-7.

Garbary, D. A. and R. F. Scagel. 1979. Scanning electron microscopy of Clathromorphum spp. (Corallinaceae, Rhodophyta). Proc. microscop. Soc. Canada 6: 14-15.

Heydrich, F. 1909. Carpogonium und Auxiliarzelle einiger Melobesiae. Ber: dt. bot. Ges. 27: 79-84.

Keats, D. W. and Y. M. Chamberlain. 1993. Sporolithon ptychoides Heydrich and $S$. episporum (Howe) Dawson: two crustose coralline red algae (Corallinales, Sporolithaceae) in South Africa. S. Afr. J. Bot. 59: 541-550.

Keats, D. W. and Y. M. Chamberlain. 1994. Three species of Hydrolithon (Rhodophyta, Corallinaceae) from South Africa: Hydrolithon onkodes (Heydrich) D. Penrose \& Woelkerling, $H$. superficiale sp. nov. and $H$. samoënse (Foslie) comb. nov. S. Afr. J. Bot. 60: 8-21.

Keats, D. W. and Y. M. Chamberlain. 1995. Heydrichia groeneri sp. nov.: a new species of crustose coralline alga (Rhodophyta, Sporolithaceae) from South Africa and Namibia. Phycologia 34: 51-57.

Keats, D. W., A. Groener and Y. M. Chamberlain. 1993. A new type of tissue sloughing in the littoral zone coralline alga Spongites yendoi (Rhodophyta, Corallinales). Phycologia 32: 143-150.

Kylin, H. 1928. Entwicklungsgeschichtliche Florideenstudien. Acta Univ. Lund. N. F. Avd. 2, 24: 41-127.

Lebednik, P. A. 1977 a. The Corallinaceae of northwestern North America. I. Clathromorphum Foslie emend. Adey. Syesis 9: 59-112.

Lebednik, P. A. 1977 b. Postfertilization development in Clathromorphum, Melobesia and Mesophyllum with comments on the evolution of the Corallinaceae and the Cryptonemiales (Rhodophyta). Phycologia 16: 379406. Addendum: Phycologia 17: 358 (1978).

Lebednik, P. A. 1978. Development of male conceptacles in Mesophyllum Lemoine and other genera of the Corallinaceae (Rhodophyta). Phycologia 17: 388-395.

Lee, R. K. S. 1970. Developmental morphology of the crustaceous alga Melobesia mediocris. Can. J. Bot. 48: 437446.

Masaki, T. 1968. Studies on the Melobesioideae of Japan. Mem. Fac. Fish. Hokkaido Univ. 16: 1-80. 
Mason L. R. 1953. The crustaceous coralline algae of the Pacific Coast of the United States, Canada and Alaska. Univ. Calif. Publs Bot. 26: 313-390.

Mendoza, M. L. and J. Cabioch. 1986. Critique et comparaison morphogénétique des genres Clathromorphum et Antarcticophyllum (Rhodophyta, Corallinaceae). Conséquences biogéographiques et systématiques. Cah. Biol. mar. 26: 251-266.

Suneson, S. 1937. Studien über die Entwicklungsgeschichte der Corallinaceen. Acta Univ. Lund. N. F. Adv. 233 (2): $1-102$.
Townsend, R. A., Y. M. Chamberlain and D. W. Keats. 1994. Heydrichia w'oelkerlingii gen. et sp. nov. a newly discovered non-geniculate red alga (Corallinales, Rhodophyta) from Cape Province, South Africa. Phycologia 33: 177-186.

Wilks, K. M. and W. J. Woelkerling. 1991. Southern Australian species of Melobesia (Corallinaceae, Rhodophyta). Phycologia 30: 507-533.

Woelkerling, W. J. 1988. The Coralline Red Algae: An Analysis of the Genera and Subfamilies of Nongeniculate Corallinaceae. Oxford University Press, Oxford and British Museum (Natural History), London. $x i+268$ pp. 
